\title{
Evaluation of physico-chemical properties of Portland cements and MTA
}

\author{
Jorge Luis Gonçalves ${ }^{(a)}$ \\ Raqueli Viapiana(a) \\ Carlos Eduardo Saraiva Miranda ${ }^{(b)}$ \\ Álvaro Henrique Borges ${ }^{(c)}$ \\ Antônio Miranda da Cruz Filho(d)
}

\footnotetext{
(a) Master in Endodontics; (b)PhD, Assistant Professor - School of Dentistry, University of Ribeirão Preto (UNAERP), Ribeirão Preto, SP, Brazil.

(c) PhD, Assistant Professor, School of Dentistry of University of Cuiabá (UNIC), Cuiabá, MT, Brazil.

(d) PhD, Assistant Professor, Department of Restorative Dentistry, School of Dentistry, University of São Paulo (USP), Ribeirão Preto, SP, Brazil.
}

\begin{abstract}
The purpose of this study was to evaluate the hydrogenionic potential and electrical conductivity of Portland cements and MTA, as well as the amount of arsenic and calcium released from these materials. In Teflon molds, samples of each material were agitated and added to plastic flasks containing distilled water for 3, 24, 72 and $168 \mathrm{~h}$. The results were analyzed with a Kruskal-Wallis non-parametric test for global comparisons and a Dunn-Tukey test for pairwise comparisons. The results revealed no significant differences in the $\mathrm{pH}$ of the materials $(p>0.05)$. The electrical conductivity of the cements were not statistically different $(\mathrm{p}>0.05)$. White non-structural cement and MTA BIO released the largest amount of calcium ions into solution $(\mathrm{p}<0.05)$, while arsenic release was insignificant in all of the materials $(p>0.05)$. The results indicated that the physico-chemical properties of Portland cements and MTA were similar. Furthermore, all materials produced an alkaline environment and can be considered safe for clinical use because arsenic was not released. The electrical conductivity and the amount of calcium ions released into solution increased over time.
\end{abstract}

Descriptors: Endodontics; Mineral trioxide aggregate; Root canal filling materials.

\section{Introduction}

In the 1990's, a research team led by Professor Mahmoud Torabinejad developed mineral trioxide aggregate (MTA), a novel retrofilling material. ${ }^{1}$ A patent for MTA was granted in $1999,{ }^{2}$ and the material was commercialized as ProRoot MTA ${ }^{\circledR}$. According to the manufacturer, this material is composed of $50-75 \%$ calcium oxide and $15-25 \%$ silicium dioxide. ${ }^{3,4}$ Studies revealed that MTA displays similar behavior to type 1 ordinary Portland cement ${ }^{5}$ with bismuth oxide, ${ }^{6,7}$ which is added to improve the radiopacifier properties of the material. ${ }^{8}$

In dentistry, Portland cements have been studied extensively as a substitute for MTA. Due to the presence of iron, the materials can be white or gray in color. ${ }^{7,8}$ White Portland cement is classified as either structural or non-structural cement. ${ }^{9}$ Non-structural cement contains minor amounts of clinker and gypsum (50-74\%), which alters the structural properties of the material. For example, clinker increases the resistance of the material and decreases its solubility. ${ }^{9}$ Portland cement and MTA display similar antimicrobial activity, ${ }^{6}$ biocompatibility, ${ }^{4}$ sealing ability, marginal adaptation, ${ }^{10}$ tissue and perirradicular healing, ${ }^{11}$ dentine barri- 
er formation, ${ }^{12}$ dimensional stability ${ }^{13}$ and moisture tolerance. ${ }^{14}$

Portland cement and MTA are rich in calcium oxide, which is converted to calcium hydroxide in aqueous solution. ${ }^{15}$ The dissociation of calcium and hydroxyl ions increases the $\mathrm{pH}$ of the solution and promotes an unfavorable environment to bacterial growth. ${ }^{6}$ Alternatively, an increase in the $\mathrm{pH}$ and calcium ion concentration improves biocompatibility $^{16}$ and promotes the action of cementoblasts, ${ }^{17}$ which can repair the material. ${ }^{12}$

Although the concentration of arsenic and other elements in MTA and Portland cements is low, ${ }^{18}$ the effect of these chemicals is a concern for clinical applications. To understand the physico-chemical proprieties of Portland cements and MTA, the amount of arsenic and calcium ions released from these materials must be evaluated. Moreover, the change in $\mathrm{pH}$ over time and the effect on the properties of the materials must be understood. The aim of this work was to evaluate the $\mathrm{pH}$, electrical conductivity and release of calcium ions and arsenic from Portland cements and MTA.

\section{Material and Methods}

The materials used in this study are described in Table 1.

To establish the water/powder ratio, $3 \mathrm{~g}$ of cement was weighed and a portion was added to $0.20 \mathrm{~mL}$ of distilled water to achieve the desired consistency. The amount of remaining powder was subtracted from the initial quantity. This procedure was repeated five times for each material.

\section{$\mathrm{pH}$ analysis}

For each material, 5 samples with a thickness of $1.5 \mathrm{~mm}$ and an inner diameter of $7.75 \mathrm{~mm}$ were analyzed. Each tube was sealed in a flask containing $7.5 \mathrm{~mL}$ of distilled water. The $\mathrm{pH}$ was measured (PH 30 Sensor Corning; Corning Inc., New York, NY, USA) with a pH meter at 3, 24, 72, and $168 \mathrm{~h}$ of spatulation. During the experiment, the $\mathrm{pH}$ of each sample was analyzed in the plastic recipient without liquid substitution.

\section{Electrical conductivity analysis}

After the $\mathrm{pH}$ of the material was evaluated, the sample was retained in the plastic recipient and the electrical conductivity of the solution was measured. Thus, all 5 samples of each material were analyzed with a condutivitymeter (Marconi CA-150, Piracicaba, SP, Brazil). The device was calibrated according to a calibration curve obtained from a solution of $1.412 \mu \mathrm{S} / \mathrm{cm}^{-1}$.

\section{Analysis of calcium ion release}

A total of 5 samples were analyzed for each type of material. Each tube was sealed in a flask containing $7.5 \mathrm{~mL}$ of distilled water, and the amount of calcium released from the material was determined after $3,24,72$, and $168 \mathrm{~h}$ of spatulation. The measurements were performed with an atomic absorption spectrometer (Perkin Elmer, Uberlingen, Germany) equipped with a hollow cathode calcium lamp. The following conditions were maintained: lamp current: $3 \mathrm{~mA}$; fuel: acetylene; support: oxygen; stoichiometry: reducing; wavelength: $422.7 \mathrm{~nm}$; slit: $0.2 \mathrm{~nm}$. To prevent the interference of phosphates and alkaline metals, all glassware was prewashed with $5 \%$ nitric acid. A standard solution of $10 \mathrm{mg} /$ $\mathrm{dL}$ of calcium was diluted in 10\% EDTA to obtain standard solutions. To calibrate the apparatus for

Table 1 - The composition of tested materials.

\begin{tabular}{c|c|c}
\hline Cement & Composition & Manufacturers \\
\hline White structural & Clinker (100-75\%), Gypsum (3\%), Carbonatic Material (0-25\%) & Votorantin, Corumbá, MS, Brazil \\
\hline White non-structural & Clinker (74-50\%), Gypsum (3\%), Carbonatic Material (26-50\%) & Votorantin, Corumbá, MS, Brazil \\
\hline Gray Portland & Clinker (97\%), Gypsum (3\%) & Votorantin, Corumbá, MS, Brazil \\
\hline MTA BIO & Portland Cement (80\%), Bismuth oxide (20\%) Ângelus Ind.Prod. Odontol., Londrina, PR, Brazil \\
\hline White ProRoot MTA & Portland Cement (75\%), Bismuth oxide (20\%), Gypsum (5\%) & Dentsply, Tulsa, OK, USA \\
\hline
\end{tabular}


zero absorbency, 10\% EDTA was used as a blank. The calcium concentration of the samples was determined according to a calibration curve of solutions with known concentrations of calcium $(0.025,0.05$, $0.1,0.2$, and $0.3 \mathrm{mg} / \mathrm{dL}$ ).

\section{Arsenic release}

Excess solution from previous tests was diluted with $\mathrm{HCl}$ (Merck, Darmstadt, Germany), which lowered the $\mathrm{pH}$ to 2.0. The solution was acidified to guarantee that arsenic was released in the form of arsenic III. For the atomic absorption spectrometry, the following operating conditions were maintained: 3 psi of nitrogen at a flow rate of $50 \mathrm{~mL} /$ $\mathrm{min}, 10 \mathrm{~mol} / \mathrm{L}$ of $\mathrm{HCl}$ at a flow rate of $1 \mathrm{~mL} / \mathrm{min}$, $1 \%$ sodium borohydride in $1 \%$ sodium hydroxide solution at a flow rate of $1 \mathrm{~mL} / \mathrm{min}$, sample flow rate of $8 \mathrm{~mL} / \mathrm{min}$ and an integration time of $90 \mathrm{~s}$. Atomic absorption spectrophotometry was conducted at a wavelength $193.7 \mathrm{~nm}$ with a arsenic hollow cathode lamp, a slit width of 0.5 , and an air-acetylene flame. Standard solutions with arsenic concentrations of 2.0, 4.0, 6.0, 8.0 and $10.0 \mu \mathrm{g} / \mathrm{L}$ were prepared from a solution of $10.0 \mu \mathrm{g} / \mathrm{L}$ arsenic trichloride in reagent grade water at a $\mathrm{pH}$ of 2.0. In total, 5 samples were analyzed at 4 different spatulation times.

\section{Statistical analysis}

The results were compared at each time point by conducting a Kruskal-Wallis non parametric test of global comparisons and a complementary DunnTukey test of pairwise comparisons. A significance level of $5 \%$ was adopted in the statistical analysis.

\section{Results}

The average $\mathrm{pH}$ of each material is shown in Table 2. Significant differences in the $\mathrm{pH}$ of the materials were not observed ( $\mathrm{p}>0.05)$. However, the $\mathrm{pH}$ at $3 \mathrm{~h}$ of immersion was statistically different from that of other time periods $(\mathrm{p}<0.05)$. Alternatively, similar $\mathrm{pHs}$ were observed at other spatulation times ( $p>0.05$ ), as shown in Graph 1.

Table 3 presents the mean electrical conductivity of the samples over time. The results indicated that the conductivity of the materials were not statistically different $(\mathrm{p}>0.05)$. However, at $168 \mathrm{~h}$, a significant difference in conductivity was observed $(\mathrm{p}<0.05)$. Alternatively, at 24 and $72 \mathrm{~h}$, differences were not observed between samples $(p>0.05)$, but these results were different from those obtained at $3 \mathrm{~h}(\mathrm{p}<0.05)$ (Graph 2).

Table 4 presents the average amount of calcium released from the materials. The results indicated that the amount of calcium released from white non-structural was statistically similar to that of MTA BIO ( $p>0.05)$, but was different $(\mathrm{p}<0.05)$ from that of the other materials. Likewise, ProRoot MTA, white structural and gray Portland released similar amounts of calcium ( $p>0.05)$. At $168 \mathrm{~h}$, the concentration of calcium released from the materi-

Table 2 - The average $\mathrm{pH}$ of the materials $(\alpha=0.05)$.

\begin{tabular}{c|c|c|c|c|c}
\hline Material & White Non-Structural & ProRoot MTA & MTA BIO & White Structural & Gray Portland \\
\hline Mean \pm SD & $11.63 \pm 0.44$ & $11.80 \pm 0.14$ & $11.81 \pm 0.11$ & $11.94 \pm 0.14$ & $12.00 \pm 0.17$ \\
\hline
\end{tabular}

Table 3 - Electrical conductivity $\left(\mu \mathrm{S} / \mathrm{cm}^{-1}\right)$ of the materials $(\alpha=0.05)$.

\begin{tabular}{c|c|c|c|c|c}
\hline Material & White Non-Structural & ProRoot MTA & MTA BIO & White Structural & Gray Portland \\
\hline Mean \pm SD & $1,677.5 \pm 1,563.4$ & $1,388.7 \pm 263.5$ & $1,294.4 \pm 407.3$ & $1,603.4 \pm 553.6$ & $1,394.8 \pm 486.8$ \\
\hline
\end{tabular}

Table 4 - Amount of calcium ions released $(\mathrm{mg} / \mathrm{dL}$ ) from the materials $(\alpha=0.05)$.

\begin{tabular}{c|c|c|c|c}
\hline Material & White Non-Structural & ProRoot MTA & MTA BIO & White Structural \\
\hline Mean \pm SD & $135.7 \pm 185.4$ & $15.64 \pm 21.3$ & $74.9 \pm 106.9$ & $8.5 \pm 12.2$ \\
\hline
\end{tabular}




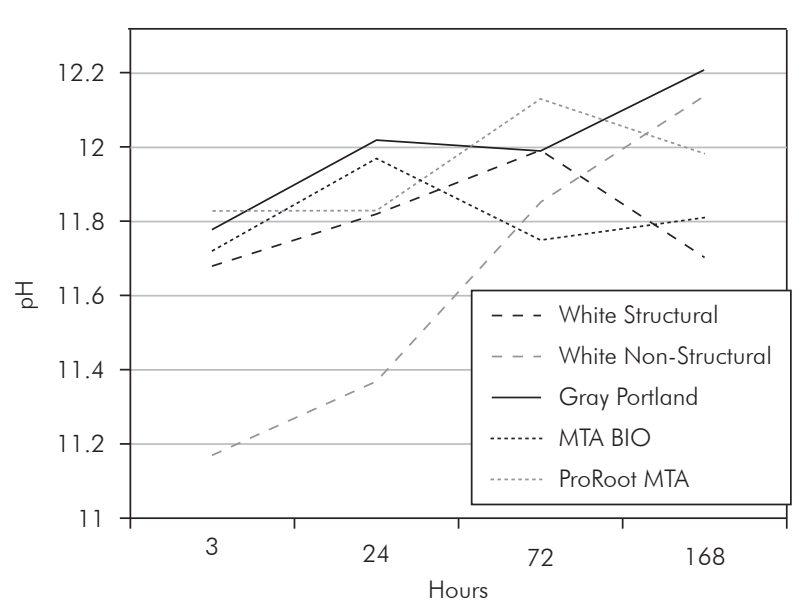

Graph 1 - pH changes of the materials according to different periods of times.

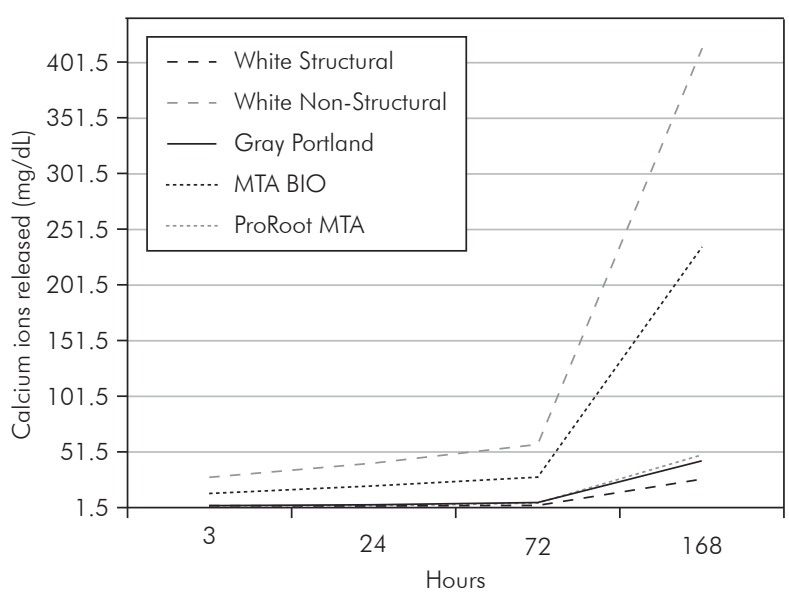

Graph 3 - Calcium ions released (mg/dL) according to periods of time.

als was different $(\mathrm{p}<0.05)$ than at other time periods, which were similar to each other $(\mathrm{p}>0.05)$, as shown in Graph 3.

Atomic absorption spectrometry and hydride generation were used to determine the amount of arsenic released from the materials. The spectrometer possessed a maximum and minimum detection limit, which specifies the range of concentrations that produce a linear response. For the chosen spectrometer, the detection interval ranged from 2 to $10 \mu \mathrm{g} / \mathrm{L}$. The equipment used to quantify the release of arsenic indicated that the concentration of arsenic released from the samples was below the lower limit

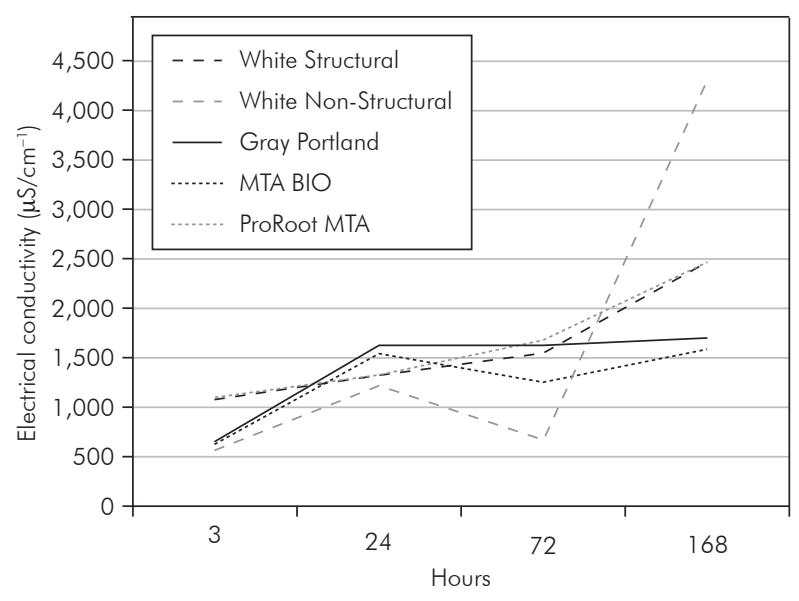

Graph 2 - Electrical conductivity $\left(\mu \mathrm{S} / \mathrm{cm}^{-1}\right)$ variation according to period of time.

of detection. Thus, the concentration of arsenic released from the materials was less than $2 \mu \mathrm{g} / \mathrm{L}$.

\section{Discussion}

Because a specific normative for retrofilling materials has not yet been developed, ${ }^{17}$ the aforementioned tests were conducted according to specification No. 57 from the ANSI/ADA ${ }^{19}$ (2000) for filling materials. During clinical use, retrofilling materials are often in close contact with periodontal tissues and are used under the same conditions as filling materials; thus, this standard was assumed to be applicable to the materials under investigation. ${ }^{8}$ However, to limit the amount of cement used in the analysis, the volume of the samples was reduced by $80 \%$, and the quality of the results was not affected..$^{20}$

The water/powder ratio was determined to verify the exact quantity of powder that should be incorporated into a specific volume of water. Portland cement is designed for civil engineering, and a specific ratio for its use in dentistry has not been established. Thus, Portland cement is often used in the same ratio as MTA cements. ${ }^{21}$ According to the MTA cement manufacturer, the recommended ratio is $3: 1,{ }^{22}$ which results in a fluid that has a consistency similar to that of soup. ${ }^{17}$ Thus, the manufacturer suggests that excess powder can be added to the mixture. The effect of additional powder on the physico-chemical characteristics of the cement is 
unknown. The results indicated that cements with different powder/liquid ratios were not statistically different $(\mathrm{p}<0.05)$. Moreover, the chemical composition of Portland cements and MTA are similar. ${ }^{5,6,7}$

Distilled water at a $\mathrm{pH}$ of 5.6 was used to evaluate the $\mathrm{pH}$ of the materials. During the first $3 \mathrm{~h}$, the samples were strongly alkaline, and the $\mathrm{pH}$ remained high until the end of the experiment. Portland cements and MTA are rich in calcium ions, which are converted to calcium hydroxide upon contact with the water. Calcium hydroxide dissociates into calcium and hydroxyl ions, which increases the $\mathrm{pH}$ of the solution. ${ }^{13}$ Thus, the variation in the concentration of calcium hydroxide leads to different $\mathrm{pH}$ values. Gray and white structural Portland cements contain large amounts of clinker; thus, these materials possessed a high $\mathrm{pH} .{ }^{9}$ Moreover, soluble forms of calcium such as calcium oxide are readily transformed into calcium hydroxide, which increases the alkalinity of the solution. ${ }^{13,23}$ However, the $\mathrm{pH}$ stabilizes over time as the solution becomes saturated with calcium hydroxide. ${ }^{24}$

Similar results were observed in studies conducted by Islam et al. ${ }^{21}$ (2006). Specifically, the $\mathrm{pH}$ of gray and white Portland cements was higher than the $\mathrm{pH}$ of gray and white MTA. Alternatively, Duarte et al. ${ }^{13}$ (2003) obtained contradictory results because the solution was removed and fresh water was added after each $\mathrm{pH}$ measurement. As a result, the $\mathrm{pH}$ of the solution decreased due to the addition of distilled water, and longer periods of time were required to achieve re-equilibration.

Electrical conductivity is directly related to the concentration of ions in the medium, which is proportional to the solubility of the material. ${ }^{23,24}$ The results indicated that the concentration of ions in solution increased as the solubility of the sample increased, which led to higher conductivity values. In general, this phenomena was observed in all of the cements. During the sample solubilization process, the components that were the most soluble in water were the first to release ions into solution. Samples components solubilize at different rates and possess different solubility products (Kps). ${ }^{24}$ Because of the complexity of these materials, the ionic equilibrium that is established is equally complex. Moreover, the common-ion effect is significant for calcium, which is the main species present in cement. ${ }^{24}$ The solubility of individual components increases as the contact time with the solvent increases; thus, the concentration of ions and the electrical conductivity increases over time. ${ }^{24}$

According to the results, the conductivity of the cements were statistically similar $(p>0.05)$, suggesting that all samples were affected similarly by solvolysis. Moreover, the volume of solvent used in the test was insufficient $(7.5 \mathrm{~mL})$. Although the conductivity significantly increased over time, the electrical conductivity should eventually stabilize due to solution saturation. ${ }^{24}$ In this study, the solution was not removed or exchanged once the samples were immersed; thus, the results obtained in this study were different from those obtained by Santos et al. ${ }^{23}$ (2005).

White non-structural cement is composed of many compounds that contain calcium. Moreover, this material is highly soluble due to the low concentration of clinker $(50-74 \%)$. Thus, high concentrations of calcium ions are released upon contact with water. ${ }^{9}$ In the presence of water, clinker reacts with other cement components, and is a strong hydraulic ligament. Therefore, the large amount of calcium released from white non-structural cement is related to the low concentration of clinker. ${ }^{9}$ White structural cement is composed of $75-100 \%$ clinker and gypsum, while gray portland cement contains $100 \%$ clinker and gypsum. ${ }^{4,25}$

MTA BIO released significantly more calcium ions into solution than ProRoot MTA. According to the manufacturer, MTA BIO contains $80 \%$ Portland cement, while ProRoot MTA contains only $75 \% .{ }^{25,26}$ The larger quantity of Portland cement in MTA BIO results in a higher concentration of clinker, which limits the solubility of the material. The main difference between MTA BIO and ProRoot is the concentration of gypsum, which is $5 \%$ higher in ProRoot. ${ }^{25,26}$ If gypsum (calcium sulfate) was not present, cement would harden immediately upon contact with water. ${ }^{3,9}$ The increase in setting time allows the components of the cement to reorganize, which produces a more resistant and durable structure. ${ }^{9}$ The results obtained in this study are in accor- 
dance with those of Duarte et al. ${ }^{13}$ (2003), which indicated that MTA Ângelus contains higher amounts of Portland cement or other calcium-related compounds than ProRoot MTA. Moreover, Oliveira et al. ${ }^{26}$ (2007) showed that the calcium concentration of MTA Ângelus was greater than that of ProRoot MTA. Thus, unlike the results of Duarte et al..$^{13}$ (2003), these authors found that the amount of ions released from the cement could be attributed to the setting time of the material as well as the original concentration of calcium.

At 3, 24 and $72 \mathrm{~h}$ of spatulation, the average concentration of calcium in solution was similar. However, at $168 \mathrm{~h}$, the amount of calcium released from the materials was statistically different. The differences in calcium concentration at extended periods of time may be attributed to the solubility of the material and the concentration of clinker. ${ }^{9}$ Individual components of the materials solubilize at different rates because each compound possesses a different solubility product $(\mathrm{Kps}) .{ }^{24}$ The results indicated that solubilization was slow during the first $72 \mathrm{~h}$; however, solubility significantly increased after extended periods of time. The high solubility and calcium concentration observed at $168 \mathrm{~h}$ can be attributed to

\section{References}

1. Torabinejad M, Chivian N. Clinical applications of mineral trioxide aggregate. J Endod. 1999 Mar;25(3):197-206.

2. Camilleri J, Pitt Ford TR. Mineral trioxide aggregate: a review of the constituents and biological properties of the material. Int Endod J. 2006 Oct;39(10):747-54.

3. Dammaschke T, Gert HUV, Zuchner H, Schäfer E. Chemical and physical surface and bulk material characterization of white ProRoot MTA and two Portland cements. Dent Mater. 2005 Aug;21(8):731-8.

4. Camilleri J, Montesin FE, Di Silvio L, Pitt Ford TR. The chemical constitution and biocompatibility of accelerated Portland cement for endodontic use. Int Endod J. 2005 Nov;38(11):83442 .

5. Wucherpfennig AL, Green DB. Mineral trioxide vs. Portland cement: two compatible filling materials. J Endod. 1999 Apr;25(4):308.

6. Estrela C, Bammann LL, Estrela C, Silva RS, Pécora JD. Antimicrobial and chemical study of MTA, Portland cement, Calcium Hidroxide Paste, Sealapex and Dycal. Braz Dent J. $2000 \mathrm{Jul} ; 1(11): 3-9$. the length of contact time between the material and the solvent. ${ }^{24}$

The concentration of trivalent arsenic (As III) was determined because it is the most toxic form of arsenic. ${ }^{18}$ In Brazil, resolution 20 of the National Council of the Environment indicates that the maximum arsenic concentration of water for human consumption is $0.05 \mathrm{mg} / \mathrm{L} .{ }^{27}$ To quantify the amount of arsenic released from the materials, atomic absorption spectrometry with hydride generation was employed. The equipment used in this study could accurately quantify the amount of arsenic at concentrations between 2 and $10 \mu \mathrm{g} / \mathrm{L}$. In all of the materials analyzed, the spectrometer could not determine the arsenic content, indicating that the concentration of this metal was below $2 \mu \mathrm{g} / \mathrm{L}$, which is safe for human consumption. ${ }^{27}$

\section{Conclusions}

In spite of several limitations, the results of this in vitro study revealed that the physico-chemical proprieties of Portland cements and MTA were similar. However, further biocompatibility studies on Portland cements should be conducted before clinical use.

7. Funteas UR, Wallace JA, Fochtman EW. A comparative analysis of Mineral Trioxide Aggregate and Portland cement. Aust Endod J. 2003 Apr;29(1):43-4.

8. Danesh G, Dammaschke T, Gert HUV, Zanbdiglari T, Schäfer E. A comparative study of selected properties of ProRoot mineral trioxide aggregate and two Portland cements. Int Endod J. 2006 Mar;39(3):213-9.

9. Associação Brasileira do Cimento Portland. Boletim técnico 106: guia básico de utilização do cimento Portland. São Paulo (SP): Associação Brasileira do Cimento Portland; 2002 Dez. 28 p.

10. Pereira CL, Cenci MS, Demarco FF. Sealing ability of MTA, Super EBA, Vitremer and amalgam as root-end filling materials. Braz Oral Res. 2004 Oct-Dec,18(4):317-21.

11. Bernabé PFE, Gomes-Filho JE, Rocha WC, Nery MJ, Otoboni-Filho JA, Dezan-Júnior E. Histological evaluation of MTA as a root-end filling material. J Endod. 2007 Oct;40(10):75865.

12. Briso ALF, Rahal V, Mestrener SR, Dezan Junior E. Biological response of pulps submitted to different capping materials. Braz. Oral Res. 2006 Jul-Sep;20(3):219-25. 
13. Duarte MAH, Demarchi ACCO, Yamashita JC, Kuga MC, Fraga SC. $\mathrm{pH}$ and calcium ion release of 2 root-end filling materials. Oral Surg Oral Med Oral Pathol Oral Radiol Endod. 2003 Mar;95(3):343-7.

14. Chong BS, Pitt Ford TR. Root-end filling materials: rationale and tissue response. Endod Top. 2005 Jul;11(1):114-30.

15. Holland R, Souza V, Nery MJ, Otoboni Filho JA, Bernabé PFE, Dezan Jr E. Reaction of rat connective tissue to implanted dentin tubes filled with Mineral Trioxide Aggregate or calcium hydroxide. J Endod. 1999 Mar;25(3):161-6.

16. Ding SJ, Kao CT, Shie MY, Hung CJ, Huang TH. The physical and cytological properties of white MTA mixed with $\mathrm{Na}_{2} \mathrm{HPO}_{4}$ as an accelerant. J Endod. 2008 Jun;34(6):74851.

17. Fridland M, Rosado R. Mineral trioxide aggregate (MTA) solubility and porosity with different water-to-powder ratios. J Endod. 2003 Dec;29(12):814-7.

18. Duarte MAH, Demarchi ACCO, Yamashita JC, Kuga MC, Fraga SC. Arsenic release provided by MTA and Portland cement. Oral Surg Oral Med Pathol Oral Radio Endod. 2005 May;99(5):648-50.

19. American National Standards Institute/American Dental Association. Specification no. 57: endodontic sealing material. Chicago (IL): ADA Publishing: 2000.

20. Carvalho-Junior JR, Correr-Sobrinho L, Correr AB, Sinhoreti MA, Consani S, Sousa Neto MD. Solubility and dimensional change after setting of root canal sealers: a proposal for smaller dimensions of test samples. J Endod. 2007 Sep;33(9):11106.

21. Islam I, Kheng Chng H, Jin Yap AU. Comparison of the physical and mechanical properties of MTA and Portland cement. J Endod. 2006 Mar;32(3):193-7.

22. Torabinejad M, Hong CU, McDonald F, Pitt Ford TR. Physical and chemical properties of a new root-end filling material. J Endod. 1995 Jul;21(7):349-53.

23. Santos AD, Moraes JCS, Araújo EB, Yukimitu K, Valério Filho WV. Physico-chemical properties of MTA and a novel experimental cement. Int Endod J. 2005 Jul;38(7):443-7.

24. Masterton WL, Hurley CN. Chemistry: principles \& reactions. 5th ed. Belmont: Brooks Cole; 2003. 756 p.

25. Ferris DM, Baumgartner JC. Perforation repair comparing two types of mineral trioxide aggregate. J Endod. 2004 Jun;30(6):422-4.

26. Oliveira MG, Xavier CB, Demarco FF, Pinheiro ALB, Costa AT, Pozza DH. Comparative chemical study of MTA and Portland cements. Braz Dent J. 2007 Jan;18(1):3-7.

27. Ministério do Meio Ambiente. Database do Conselho Nacional de Meio Ambiente [Internet]. Brasília (DF): Ministério do Meio Ambiente; 1986 [cited 2009 Fev 10]. Available from: http:// www.mma.gov.br/port/conama/legiabre.cfm?codlegi=43. 